\title{
Deixis in Spontaneous Speech of Jordanian Urban Arabic Native Speakers
}

\author{
Zainab Sa'aida \\ Department of English, Tafila Technical University, Jordan \\ E-mail: z.saaida@ttu.edu.jo
}

Doi:10.7575/aiac.alls.v.8n.1p.88

Received: $11 / 10 / 2016$

URL: http://dx.doi.org/10.7575/aiac.alls.v.8n.1p.88

Accepted: 06/01/2017

\begin{abstract}
This study aims at describing types and usages of deixis in the speech of Jordanian Urban Arabic native speakers. The present study was conducted in different settings which researcher's family members, friends, colleagues, and acquaintances took part in. Data of the study were collected through observing spontaneous speech of native speakers of Jordanian Urban Arabic. The data consist of transcriptions of deictic expressions, which were categorised into groups according to the types or usages of deictic words. The data were translated and transliterated by the researcher. The International Phonetic Alphabet symbols were used to transcribe the data. Findings of the study show that there are five types of deictic expressions in Jordanian Urban Arabic: Personal, spatial, temporal, discourse and social deixis. The current study has also described the various usages of deictic words in Jordanian Urban Arabic: gestural, symbolic, and non-deictic usage.
\end{abstract}

Keywords: Deixis, categories of deictic expressions, usages of deictic expressions, Jordanian Urban Arabic

\section{Introduction}

Every natural language has its own infinite sets of utterances. Utterances are usually made in a particular place and at a particular time. They are also made by a particular speaker and are addressed to some other person(s) called the hearer(s). According to Lyons (1968), a typical utterance is the one which is made by a speaker who is distinct from the hearer and in which both of the speaker and the hearer are in the same spatio-temporal situation in addition to the fact that it refers to a person or an object (this person or object is called the subject of discourse). Therefore, the more lexical items that refer to persons or objects, the more subjects or discourse there will be (ibid). Most words in natural languages do mean what they mean regardless of the speaker, the time, or the place that they are used in. However, there are small sets of words in mostly all natural languages which mean differently according to the speaker who made it, the place that it was made in, and the time that it was made at. These words are called deictic words and the phenomenon in which they occur is called deixis. The word deixis is from the Greek word deiktikos which means pointing reflecting the main function of deixis. The notion of deixis constitutes the focus of many different disciplines: psychology, cognitive science, and linguistics. Linguistically, studies (Fillmore 1971, 1975, 1997; Lyons 1968, 1977; Levinson 1983; Anderson and Keenan 1985; and Diessel 1999, among others) abound about the phenomenon of deixis. For Yule (1996: 9), deixis is a technical term (from Greek) for one of the most basic ones that means 'pointing via language'. Lyons (1977: 637) defines deixis as follows:

By deixis, is meant the location and identification of persons, objects, events, processes and activities talked about, or referred to, in relation to the spatio-temporal context created and sustained by the act of utterance and the participation in it, typically, of a single speaker and at least one addressee.

Describing the situation in which an utterance occurs, Lyons (1968: 275-76) states:

The typical situation of utterance is egocentric: as the role of speaker is transferred from one participant to another in a conversation, so the 'centre' of the deictic system switches ( $I$ being used by each speaker to refer to himself, you being used to refer to the hearer). The speaker is always at the centre, as it were, of the situation of utterance.

In literature (e.g. Fillmore 1971, 1975, 1997; Lyons 1968, 1977; Levinson 1983), three traditional categories of deixis have been recognized: personal deixis such as the Spanish third pronouns él 'he' and ella 'she' which are definite as against to alguien 'someone and alguna cosa 'something' which are indefinite, spatial deixis, and temporal deixis. In addition to those three traditional categories, two further categories were assumed in some studies (e.g. Levinson, 1983; cf. Lyons, 1968, 1977; and Fillmore, 1971, 1997): 'discourse deixis' and social deixis. Deictic words have different usages in languages: gestural, symbolic, or even having a non-deictic meaning (Nunberg, 1998; Levinson 2004). 


\section{Statement of Problem}

Little attention has been paid to the description of the categories of person, place, time, discourse and social deictic expressions and the various deictic and non-deictic usages of expressions in Jordanian Urban Arabic (JUA, henceforth) - a dialect spoken in Jordan. The literature (e.g. Jarbou, 2010; Al-Aqarbeh, 2015) focuses on describing some types or usages of deictic expressions in Jordanian Arabic - a language which consists of three major dialects: Jordanian Urban Arabic, Jordanian Rural Arabic and Jordanian Bedouin Arabic, in addition to other sub-related dialects among different Jordanian speakers in different cities in Jordan. JUA has its own phonological system and lexicon which differ from those of Jordanian Rural Arabic and Jordanian Bedouin Arabic; therefore, a study needs to be conducted to provide a detailed account of all types and usages of deictic expressions in spoken Jordanian Urban Arabic. Findings of the current study will add more to the literature of Jordanian Urban Arabic semantics. They will be of interest to semanticists who are unfamiliar with JUA and who are interested in cross-language studies; in other words, those who are interested in exploring linguistic parallels between languages. This article is organised as follows. The first section provides a brief introduction to the topic of this article. Section 2 presents statement of problem. The next section provides the reader with a description of the linguistic situation in Jordan. Section 4 presents methods of data collection. Section 5 presents results of the study and provides a discussion of the results. I sum up in section 6 .

\section{The Linguistic Situation in Jordan}

Jordanian Arabic is the official spoken and written language in Jordan. There are three main varieties of Jordanian Arabic: Jordanian Urban Arabic, Jordanian Rural Arabic, and Jordanian Bedouin Arabic. The present study focuses mainly on JUA - a Jordanian Arabic variety which has its own phonological system (see Sa'aida, 2015) and its own lexical stock (cf. Sa'aida, 2016). Classical Arabic is used in religious settings and some university classes of poetry. Modern Standard Arabic is the second language in Jordan; it is acquired at an early age at kindergarten or school. It is used in formal settings such as news casting, newspaper articles, and political speeches. English is considered a foreign language in the linguistic situation in Jordan; it is not used for oral or written communications by locals although it is used as a language for communicating with foreigners who live in or visit Jordan.

\section{Data Collection}

The data of the study consist of transcriptions of tokens (i.e. JUA deictic expressions). Data were collected in different settings by the researcher. The method of collecting the data was observing spontaneous speech of native speakers of JUA. Participants of the present study were researcher's family members, friends, colleagues, and acquaintances. The data were collected in different places: house, shops, workplace, and nieghbourhood. The researcher did not purposefully stimulate the course of interactions. Being a native speaker of JUA, the researcher was able to write down the tokens in a notebook immediately after the occurrence of expressions in interactions; recordings were not needed. The data were transcribed using the International Phonetic Alphabet (IPA) symbols (see appendix A). Phonemic transcriptions of the tokens, transliterations and translations were provided. The data were classified into groups according to the types or usages of deictic expressions.

\section{Results and Discussion}

This section presents the results of the current study and provides the reader with a description of the various types and usages of deictic expressions in JUA.

\subsection{Types of Deictic Expressions in JUA}

Deictic expressions in JUA can be divided into five categories: person, place, time, discourse, and social deixis. The sub-sections 5.1.1 through 5.1.5 discuss these five categories.

\subsubsection{Personal deixis}

Personal deixis refers to the notion of participant-roles; first person pronouns are used by the speaker to refer to himself/herself, the second person pronouns are used to refer to the hearer, and the third person pronouns are used to refer to things or persons other than the speaker and the hearer (Lyons, 1968). The third person differs from the first and second persons in several respects: it is necessary for the speaker and hearer to be present in the situation of utterance; however, it is not for persons or things that expressions refer to in the situation. The persons or things might even be left unidentified in the situation. Thus, the third person category can be featured as 'definite' or 'indefinite' and as 'proximate' or 'remote' in relation to the other categories (ibid). Consider the following examples from JUA.

\footnotetext{
/Pana nașahtak mba:rih, bas inta ma: smiYıt/ (said by a father to his son)

I gave advice-you-sing. yesterday, but you-sing. didn’t listen

'I gave you advice yesterday, but you didn't listen'

/Pana ra:jı̣ a:kul, ha:bib ti:zı?/ (said by Sami to his friend, Ahmad)

I am going I-eat, you-like come?

'I am eating out, would you like to join?'
}

In the sentences mentioned above in (1), there are a number of personal deictic words: / Rana/ 'I', the covert pronoun 
/Inta/ 'you.sing.' in /nașahtak/ 'gave advice', 'the pronoun / Pana/ 'I', and the covert pronoun /Inta/ 'sing. you' in /ha:brb/ 'you like'. In these examples, the deictic pronouns /?ana/ 'I' and /inta/ 'sing. you' are used to refer to different persons. In the first example, the pronoun / Pana/ 'I' apparently refers to the father and in the second example it refers to Sami. The pronoun /inta/ 'sing. you' refers to the son in the first example while it refers to Sami's friend, Ahmad, in the second example. As the examples above show, the pronoun / ?ana/ 'I' is used by male speakers in the two examples. However, the same pronoun can be also used by a female speaker of JUA. Consider the following dialogue between a mother and her son.

/PrlPumm: / fare:t Illi: wașṣe:tak Gale:?/

Mother: you-bought which I-told-you-sing. about?

'Mother: have you bought what I told you about?'

/PIlPibin: je: nsi:t/

Son: oh I-forgot.

'Son: Oh I forgot.'

/PIlPumm: ma: fi: mufkılı, Pana baftri: bukra/

Mother: no there is problem, I will buy-it tomorrow.

'Mother: no worries. I will buy it tomorrow.'

/PılPıbın: Pana ța:lıS mıfwa:r Ilmasa, bazi:bu maSı wana za:j/

Son: I I-am going out in the evening, I-bring-it with-me while-I coming.

'Son: I am going out tonight; I will bring it with me.'

In this example, both the mother and her son use the pronoun / Rana/ 'I' to refer to themselves. When the mother said, 'ma: fi: mufkilı, Pana baftri: bukra', she used the pronoun /Rana/ 'I' to refer to herself. Similarly, the son used the same pronoun when he said, 'Pana ța:lı mIJwa:r ilmasa, bazi:bu maSı wana za:j' with reference to himself.

\subsubsection{Spatial deixis}

Spatial or place deixis concerns with locations relevant to an utterance. The locations may be either those of the speaker and the hearer or those of referents. Examples of place deictic words from English are the adverbs here and there and the demonstratives this and that. Diessel (2012: 3) states:

Deictic expressions are used to indicate a location or point in time relative to the deictic centre. For instance, the spatial adverbs here and there can be used to express a contrast between two different locations based on their relationship to the origo (or deictic centre; added by the researcher): here marks the area that is conceptualized as the deictic centre, and there indicates a location that is not included in this area $[\ldots]$ the deictic centre is the centre of a coordinate system that underlies the conceptualization of the speech situation. In the unmarked case, the deictic centre is defined by the speaker's location at the time of the utterance.

Motion verbs like 'go' and 'come', 'take' and 'bring' have a deictic ingredient, because they contain the meanings 'towards the speaker' or 'away from the speaker'. The following sentences illustrate the use of the proximal deictic word /ho:n/ 'here' in JUA.

a. / Jare:t Il Pawa:Si min ho:n/ (said by Sarah to her friend at a clothes shop).

I-bought the clothes from here.

'I got the clothes from here'.

b. /kunna sa:kni:n ho:n/ (said by Sami to his friend at a street).

We-used to living here.

'We used to live here'.

c. /fi: ho:n nwa: $\quad$ kti:ri/ (said by Ali to his kids at a zoo).

There are species many.

'There are many species here'.

The examples in (3) illustrate that the referent of / ho:n/ 'here' varies with the conceptualization of the speech situation. In the examples in (3) the deictic centre includes an area that is organized around the speaker's location at the time of the utterance. In (3.a) the deictic centre is the clothes shop where the speech event is taking place between Sarah and her 
friend, in (3b) the deictic centre is the street, and it is the zoo in $(3 \mathrm{c})$.

\subsubsection{Temporal deixis}

Temporal or time deixis concerns with time relevant to the event of utterance. The concept of time is represented by three different classes of expressions: tense or grammatical expressions (i.e. inflections or auxiliaries), adverbs of time (simple temporal deictics) such as today, yesterday, and now, and complex time adverbials (lexically composite expressions) such as ten years ago and ten years from now (Comrie, 1985). Consider the following examples from JUA.

(4) a. /ruhna Iljo:m laSindha/ (said by Sarah on $1^{\text {st }}$ November, 2016).

We-went today to-with her.

'We visited her today'.

b. /ruhna Iljo:m laSindha/ (said by Sarah on $1^{\text {st }}$ December, 2016).

We-went today to-with her.

'We visited her today'.

c. /ruhna Iljo:m laSindha/ (said by Sarah on $2^{\text {st }}$ December, 2016).

We-went today to-with her.

'We visited her today'.

What the examples in (4) illustrate is that the deictic word /Iljo:m/ 'today' takes some elements of its meaning from the time relevant to the event of utterance. In (4a) the deictic word /Iljo:m/ 'today' refers to $1^{\text {st }}$ November, 2016, in (4b) it refers to $1^{\text {st }}$ December, 2016, and to $2^{\text {st }}$ December, 2016 in $(4 \mathrm{c})$.

\subsubsection{Discourse deixis}

Discourse deictic expressions encode reference to parts of the discourse which contains the utterance. Consider the following examples from JUA.
a. /ha:j blu:zı ḥamra/.
This blouse red.
This is a red blouse.
b. /ṣo:tu ka:n zaj he:k: bum/
Its-sound was like this: boom.
'It sounded like this: boom'.
c. /k:n hada:k ḥafil bizannın/.
Was that a party amazing.
'That was an amazing party'.

In (5a) and (5b) the deictic words /ha:j/ 'this' and /he:k/ 'this' refer to an upcoming portion of the discourse, and the deictic word /hada: $\mathrm{k} /$ 'that' in $(5 \mathrm{c})$ refers to a prior portion of the discourse.

\subsubsection{Social deixis}

Social deictic expressions encode aspects of the social relationship that holds between the speaker and the hearer or the speaker and some referents. The social information that is encoded in language is of two kinds: relational and absolute (Levinson, 1979). There are different relations that are typically expressed: the relation between speaker and referent, speaker and addressee, speaker and bystander, and speaker and setting (ibid). An example of the relation between speaker and addressee is the familiar example of Tu/Vous (singular and plural versions of 'you'). When a language has two different second-person pronouns, it is said to have T-V distinctions. Consider the following examples from JUA.

(6) a. /inta Illi rbıht Ilza:?izi/ (said by Ali to his friend).

You-sing. who won the-prize.

'You were the one who won the prize'.

b. /intu Illi rbihtu Ilza:?ızi/ (said by Ali to a person who he met for the first time).

You-pl. who won the-prize.

'You were the one who won the prize'. 
In (6a) the second-person singular pronoun /Inta/ 'you' is used to indicate familiarity between Ali and his friend; however, the plural pronoun /Intu/ 'you' has a sort of formality. Example of the second kind of social information which is encoded in JUA - i.e. absolute - are the JUA titles of addressee /Cuțu:ftak/ 'your excellency', 'maSa:li:k/ 'your excellency'.

Findings of the present study (provided in 5.1.1 through 5.1.5) agree with what Fillmore (1971, 1975, 1997), Lyons (1968, 1977), and Levinson (1983) found in their studies on different languages; JUA has five types of deictic expressions: personal, temporal, spatial, discourse, and social deictic expressions. The present study has provided a detailed account of types of deictic expressions in a particular dialect of Jordanian Arabic, JUA, in contrast to other previous studies (e.g. Jarbou, 2010; Al-Aqarbeh, 2015) which focused on mostly one or two types of deixis in Jordanian Arabic in general with no focus on particular dialect of Jordanian Arabic. It is necessary to study deictic expressions in a particular dialect of Jordanian Arabic, as each Jordanian dialect has its own phonological system and lexicon. Accordingly, findings of the current study added more to the literature of semantics of Jordanian Arabic in general and JUA in particular, and filled gaps that were left with no account in the literature. The following section discusses usages of deictic expressions in JUA.

\subsection{Usages of Deictic Expressions}

Deictic expressions in JUA can have a deictic or a non-deictic usage. When they are used as deictic words, they have either gestural or symbolic usages.

\subsubsection{Gestural usage}

Gestural deictics are those expressions that one needs some sort of audio-visual information to understand them. The following examples from JUA illustrate the gestural usage of deictic words.

a. Zarahıt Ilıṣbaৎ ha:d/ (said by May holding up her index).

I-cut the-finger this.

I cut this finger.

b. / Jare:t Ilko:t hada:k/ (said by Maha pointing at a coat in a shopping window).

I-bought the-coat that.

I bought that coat.

In the example (10a) the hearer needs to see which finger is being held up in order to be able to understand which finger that the speaker is talking about. The demonstrative /ha: $d$ / 'this' refers to May's index finger. Similarly, in (10b) the hearer is able to recognize the coat that Maha is talking about, as Maha is pointing at a particular coat at the clothes shop. Therefore, the demonstrative /hada:k/ 'that' refers to the coat that Maha is pointing at.

5.2.2 Symbolic usage

Symbolic deictics are those expressions that one needs only basic spatio-temporal knowledge to understand them. Consider the following examples from JUA which illustrate the symbolic usage of deictic expressions.

a.

$$
\begin{gathered}
\text { Sama is in Amman at the moment. She says, '/habbe:t ha:j Ilmadi:nI/'. } \\
\text { I-liked this the-city. } \\
\text { 'I liked this city'. }
\end{gathered}
$$

b. Sali is in Amman on $2^{\text {nd }}$ December, 2016. She says, '/Ilzaww iljo:m hiluww'/'.

$$
\begin{aligned}
& \text { I-liked this the-city. } \\
& \text { 'I liked this city'. }
\end{aligned}
$$

In (11a) the speaker uses /ha:j Ilmadi:nI/ 'this city' to refer to Amman - in this example the hearer needs only knowledge of the current location to recognize the city that the speaker is talking about. In (11b) the hearer needs only knowledge of the current time to understand that / $\mathrm{Iljo:m/} \mathrm{'today'} \mathrm{is} \mathrm{used} \mathrm{to} \mathrm{refer} \mathrm{to} 2^{\text {nd }}$ December, 2016.

\subsubsection{Non-deictic usage}

Some deictic expressions might be used for a non-deictic usage. Consider the following example from JUA.

$$
\text { Razan said, ‘/ruhıt la ha:j ılmadi:nı marrah/'. }
$$

I-went to this the-city once.

'I went to this city one time'. 
In (12) the speaker uses the word /ha:j/ 'this' as an indefinite article a; the utterance here is used to mean 'I went to a city one time'.

The present study has been the first in its scope in Jordan to provide an account of usages of deictic expressions in a particular dialect of Jordanian Arabic, JUA. Findings of the study, provided in 5.2.1 through 5.2.3, agree with the findings of Nunberg (1998) and Levinson (2004) - deictic expressions have three usages in a language: gestural, symbolic, and non-deictic.

\section{Conclusion}

The types and usages of deictic expressions in JUA have been described in the present study. The types of deictic expressions include: personal, spatial, temporal, discourse, and social deictic words. Deictic expressions in JUA might be used for gestural, symbolic or non-deictic usages. Motion verbs like 'go' and 'come', 'take' and 'bring' have a deictic ingredient in JUA, because they contain the meanings 'towards the speaker' or 'away from the speaker'. Further study needs to be conducted to explore types and usages of deictic expressions in other Jordanian dialects (i.e. Jordanian Rural Arabic and Jordanian Bedouin Arabic).

\section{References}

Al-Aqarbeh, R. (2015). Temporal interpretation in Standard and Jordanian Arabic. Dirasat: Human \& Social Sciences, 42 (3), 999-1026.

Anderson, S. \& Edward L. (1985). Deixis. In T. Shopen (Ed.), Language Typology and Syntactic Description, 3, (pp. 259-308). Cambridge: Cambridge University Press.

Comrie, B. (1985). Tense. Cambridge: Cambridge University Press.

Diessel, H. (1999). Demonstratives: Form, function, and grammaticalization. Amsterdam: Benjamins.

Diessel, H. (2012). Deixis and demonstratives. In C. Maienborn, K. von Heusinger \& P. Portner (Eds.), Semantics (HSK 33.3) (pp. 1-25), De Gruyter.

Fillmore, C. (1971). Towards a theory of deixis. Working papers in linguistics. Hawaii: University of Hawaii.

Fillmore, C. (1975). Santa Cruz lectures on deixis. Bloomington, Indiana: Indiana University Linguistics Club.

Fillmore, C. (1997). Lectures on Deixis. Stanford: CSLI Publications.

Jarbou, S. (2010). Accessibility vs. physical proximity: An analysis of exophoric demonstrative practice in Spoken Jordanian Arabic. Journal of Pragmatics, 42, 3078-3097.

Levinson, S. (1979). Pragmatics and social deixis: Reclaiming the notion of conventional implicature. Proceedings of the Fifth Annual Meeting of the Berkeley Linguistics Society, 206-223.

Levinson, S. (1983). Pragmatics . Cambridge: Cambridge University Press.

Levinson, S. (2004). Deixis. In L. Horn \& G. Ward, The handbook of pragmatics (pp. 97-121). Oxford: Blackwell.

Lyons, J. (1968). Introduction to theoretical linguistics. London: Cambridge University Press.

Lyons, J. (1977). Semantics. Cambridge: Cambridge University Press.

Nunberg, G. (1998). Indexicality and deixis. In A. Kasher (Ed.), Pragmatics: Critical concepts (pp. 145-184). London: Routledge.

Sa'aida, Z. (2015). Aspects of the phonology of English loanwords in Jordanian Urban Arabic: A distinctive feature, moraic, and metrical stress analysis (Unpublished $\mathrm{PhD}$ thesis). University of Leeds, UK.

Sa'aida, Z. (2016). Expanding the lexicon: The case of Jordanian Arabic. Advances in Language and Literary Studies, 7(6), 9-14.

Yule, G. (1996). Pragmatics. Oxford: Oxford University Press.

\section{Appendix A}

\section{List of JUA Phonemic symbols}

1. $/ \mathrm{t} /$ : voiceless plain dental plosive.

2. $/ \mathrm{t} /:$ voiceless emphatic dental plosive.

3. $/ \mathrm{k} /$ : voiceless velar plosive.

4. /q/: voiceless uvular plosive.

5. / / /: voiceless glottal plosive.

6. /b/: voiced bilabial plosive.

7. $/ \mathrm{d} /$ : voiced plain dental plosive.

8. /ạ/: voiced emphatic dental plosive. 
9. /f/: voiceless labiodental fricative.

10. /s/: voiceless plain alveolar fricative.

11. /ṣ/: voiceless emphatic alveolar fricative.

12. $/ \mathrm{J} /$ : voiceless post-alveolar fricative.

13. $/ \mathrm{x} /$ : voiceless velar fricative.

14. $/ \mathrm{h} /$ : voiceless pharyngeal fricative.

15. $/ \mathrm{h} /$ : voiceless glottal fricative.

16. /z/: voiced plain alveolar fricative.

17. /ẓ/: voiced emphatic alveolar fricative.

18. /3/: voiced post-alveolar fricative.

19. $/ \mathrm{y} /$ : voiced velar fricative.

20. / / /: voiced pharyngeal varies between fricative and approximant.

21. $/ \mathrm{m} /$ : bilabial nasal.

22. /n/: alveolar nasal.

23. /1/: alveolar lateral.

24. /r/: alveolar trill.

25. /w/: labial-velar glide.

26. $/ \mathrm{j} /:$ : palatal glide.

27. /i/: high front short vowel.

28. /u/: high back rounded short vowel.

29. /a/: low central short vowel.

30. /i:/: high front long vowel.

31. /u:/: high back rounded long vowel.

32. /a:/: low front long vowel.

33. /e:/: mid front long vowel.

34. /o:/: mid back rounded long vowel. 